\title{
Pseudolabrys taiwanensis gen. nov., sp. nov., an alphaproteobacterium isolated from soil
}

\author{
Peter Kämpfer, ${ }^{1}$ Chiu-Chung Young, ${ }^{2}$ A. B. Arun, ${ }^{2}$ Fo-Ting Shen, ${ }^{2}$ \\ Udo Jäckel, ${ }^{1}$ Ramon Rosselló-Mora, ${ }^{3}$ Wei-An Lai ${ }^{2}$ and P. D. Rekha ${ }^{2}$ \\ ${ }^{1}$ Institut für Angewandte Mikrobiologie, Justus-Liebig Universität Giessen, IFZ - Heinrich-Buff- \\ Ring 26-32, D-35392 Giessen, Germany \\ ${ }^{2}$ College of Agriculture and Natural Resources, Department of Soil and Environmental \\ Sciences, National Chung Hsing University, Taichung 402, Taiwan, ROC \\ ${ }^{3}$ Grup d'Oceanografia Interdisciplinari, Institut Mediterrani d'Estudis Avançats (CSIC-UIB), \\ Esporles, Mallorca, Spain
}

Correspondence

Peter Kämpfer

peter.kaempfer@agrar.uni-

giessen.de

\begin{abstract}
A Gram-negative, short rod-shaped micro-organism (CC-BB4 ${ }^{\top}$ ) was isolated on nutrient agar from soil from Sinshe in Taichung County, Taiwan. Analysis of the 16S rRNA gene sequence demonstrated that this isolate was novel, as it showed $<92 \%$ similarity to the sequences of species of the genera Labrys, Beijerinckia and Methylocystis. The micro-organism did not utilize methylamine or methanol as a substrate, but was able to use several organic acids. The fatty acid profile was different from those reported for the genera Labrys, Beijerinckia, Methylocystis, Angulomicrobium, Methylorhabdus and Methyloarcula. On the basis of the 16S rRNA gene sequence analysis, in combination with chemotaxonomic and physiological data, strain CC-BB4 ${ }^{\top}$ represents a novel genus, for which the name Pseudolabrys gen. nov. is proposed. The type species is Pseudolabrys taiwanensis sp. nov., and the type strain of $P$. taiwanensis is CC-BB4 ${ }^{\top}$ (=CCUG $51779^{\top}=$ CIP $108932^{\top}$ ).
\end{abstract}

During the characterization of organisms in oxisol-type (red) soil samples from a location called Sinshe in Taichung County, Taiwan, strain $\mathrm{CC}-\mathrm{BB} 4^{\mathrm{T}}$ was isolated and maintained on nutrient agar (NA; Oxoid) after incubation at $32{ }^{\circ} \mathrm{C}$ for 1 week. Subcultivation was performed on tryptone soy agar (TSA; Oxoid) at $30^{\circ} \mathrm{C}$ for between $24 \mathrm{~h}$ and 7 days. On this agar, $\mathrm{CC}-\mathrm{BB} 4^{\mathrm{T}}$ was able to grow at $15-36^{\circ} \mathrm{C}$, but not at 10 or $45^{\circ} \mathrm{C}$. The organism was able to grow on NA, TSA and R2A agar (Oxoid). Gram staining was performed as described by Gerhardt et al. (1994). Phenotypic tests were performed according to Kämpfer et al. (1991), and further physiological tests [API ZYM enzyme profiles (bioMérieux), API 20E (bioMérieux), Biolog GN2 system] were done according to the instructions of the relevant manufacturer. Flexirubin-like pigments were observed by flooding the plates with $20 \%(\mathrm{w} / \mathrm{v})$ potassium hydroxide (Fautz \& Reichenbach, 1980). Fluorescence was tested $48 \mathrm{~h}$ after plating on King's B medium. DNA used for the determination of $\mathrm{G}+\mathrm{C}$ content was isolated by using the UltraClean microbial DNA isolation kit according to the instructions of the manufacturer (MOBIO). The DNA G $+\mathrm{C}$ content was determined as described previously (Peña et al., 2005). Cell morphology was observed under a Zeiss light microscope at

The GenBank/EMBL/DDBJ accession number for the 16S rRNA gene sequence of strain CC-BB4 ${ }^{\top}$ is $\mathrm{DQ} 062742$. $\times 1000$ magnification, using cells that had been grown for 3 days at $30^{\circ} \mathrm{C}$ on $\mathrm{NA}$; the results are given in the species description. The $16 \mathrm{~S}$ rRNA gene sequence was analysed as described previously (Kämpfer et al., 2003; Young et al., 2005).

Analysis of the sequence data was performed by using the software package MEGA, version 2.1 (Kumar et al., 2001), after multiple alignment of the data by CLUSTAL $\mathrm{X}$ (Thompson et al., 1997). A distance-matrix method (distance options according to the Kimura two-parameter model), including clustering by the neighbour-joining method (Fig. 1) and a discrete character-based maximumparsimony method, was used. In each case, bootstrap values were calculated from 1000 replications. The $16 \mathrm{~S}$ rRNA gene sequence of strain $\mathrm{CC}-\mathrm{BB} 4^{\mathrm{T}}$ was a continuous stretch of $1386 \mathrm{bp}$. Sequence-similarity calculations indicated that strain CC-BB4 ${ }^{\mathrm{T}}$ showed the greatest degree of similarity with Labrys monachus VKM B-1479 $(91 \cdot 3 \%)$, Labrys methylaminiphilus JLW10 ${ }^{\mathrm{T}}(91 \cdot 3 \%)$ and Bradyrhizobium japonicum DSM $30131^{\mathrm{T}}(91 \cdot 3 \%)$. Lower sequence similarities $(<91 \%)$ were found with respect to members of all other genera shown in Fig. 1.

Fatty acid analyses were performed as described by Kämpfer $\&$ Kroppenstedt (1996), and the fatty acid profile of strain $\mathrm{CC}-\mathrm{BB} 4^{\mathrm{T}}$ (given in the species description) was found to be 


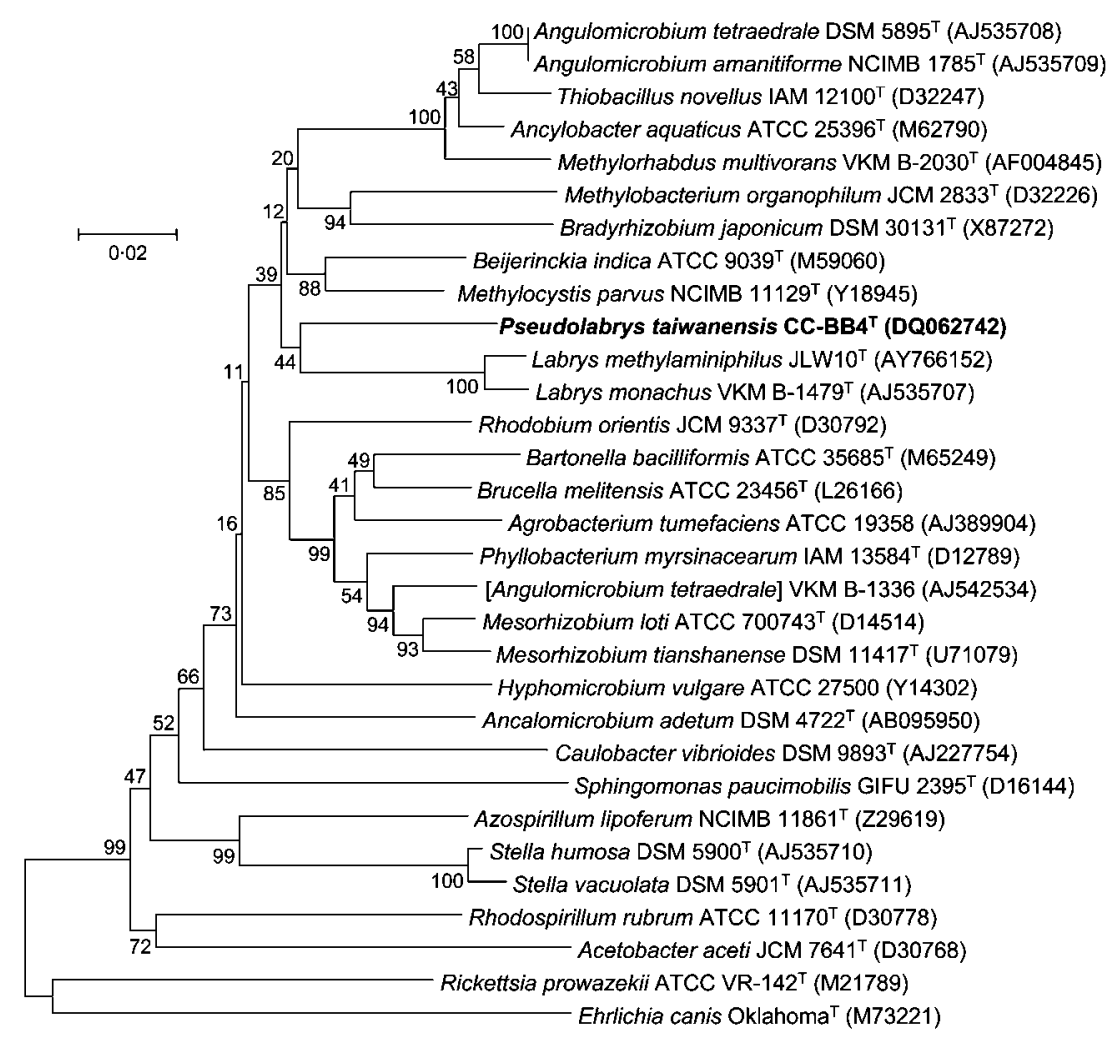

Fig. 1. Neighbour-joining phylogenetic tree, based on 16S rRNA gene sequences available from the EMBL database (accession numbers are given in parentheses), constructed after multiple alignment of the data by CLUSTAL X (Thompson et al., 1997). Distances (distance options according to the Kimura two-parameter model) and clustering were performed using MEGA, version 2.1 (Kumar et al., 2001). Bootstrap values based on 1000 replications are shown as percentages at branching points. Bar, 0.02 substitutions per nucleotide position. similar to those of the genera listed in Table 1, although significant differences were also found.

The results of the physiological characterization, achieved using methods described previously (Kämpfer et al., 1991; Kämpfer, 1990), are given in the species description and in Table 1. The utilization of methanol, methylamine, formaldehyde and formamide ( 1 and $5 \mathrm{mM}$ in each case) was tested in the medium described by Widdel \& Bak (1992). The presence of the mxaF gene (McDonald \& Murrell, 1997), which encodes the $\alpha$-subunit of the methanol dehydrogenase present in all methylotrophs (Hanson \& Hanson, 1996; McDonald et al., 1995), was tested with the PCR assay described by McDonald \& Murrell (1997); DNA extracted from Methylosinus trichosporium $\mathrm{OB} \mathrm{b}^{\mathrm{T}}$ was used as the positive control. No positive PCR amplification products were obtained with this test. In conclusion, strain $\mathrm{CC}-\mathrm{BB} 4^{\mathrm{T}}$ is not a methylotrophic bacterium. No flexirubinlike or fluorescent pigments were observed. Strain CC-BB4 ${ }^{\mathrm{T}}$ was unable to produce acid from various carbohydrates, but tests with organic acids as the carbon substrates gave positive results. In the API $20 \mathrm{E}$ test, strain CC-BB4 ${ }^{\mathrm{T}}$ was positive only for the Voges-Proskauer (acetoin) reaction; in the API ZYM enzyme profiling test, $\mathrm{CC}-\mathrm{BB} 4^{\mathrm{T}}$ was positive for esterase, esterase lipase, lipase (weakly), leucine arylamidase and naphthol-AS-BI-phosphohydrolase. On the basis of these results, we propose that strain CC-BB4 ${ }^{\mathrm{T}}$ should be classified within a novel genus, Pseudolabrys gen. nov., as the type strain of Pseudolabrys taiwanensis sp. nov.

\section{Description of Pseudolabrys gen. nov.}

Pseudolabrys (Pseu.do.la'brys. Gr. adj. pseudes false; N.L. masc. n. Labrys a bacterial genus name; N.L. masc. n. Pseudolabrys the false Labrys).

Cells are Gram-negative, aerobic, non-motile and short rodshaped. Reproduction of cells is by division and not by budding. Methanol, methylamine, formaldehyde and formamide are not used as sole sources of carbon. Growth occurs after $96 \mathrm{~h}$ incubation on TSA and NA at $30^{\circ} \mathrm{C}$. The major fatty acids are $\mathrm{C}_{16: 0}, \mathrm{C}_{18: 1} \omega 7 c$ and $\mathrm{C}_{19: 0}$ cyclo $\omega 8 c$. The DNA G + C content is $67 \mathrm{~mol} \%$. The type species is Pseudolabrys taiwanensis.

\section{Description of Pseudolabrys taiwanensis sp. nov.}

Pseudolabrys taiwanensis (tai.wan.en'sis. N.L. masc. adj. taiwanensis of Taiwan, where the type strain was isolated).

Shows the following properties in addition to those given in the genus description. Oxidase- and catalase-positive. The fatty acid profile of the type strain comprises iso- $\mathrm{C}_{15: 0}$ $(0 \cdot 8 \%), \mathrm{C}_{16: 0}(4 \cdot 8 \%)$, iso- $\mathrm{C}_{15: 0} 3-\mathrm{OH}(2 \cdot 0 \%)$, iso$\mathrm{C}_{17: 1} \omega 9 \mathrm{c}(0 \cdot 8 \%)$, iso- $\mathrm{C}_{17: 0} \quad(6 \cdot 1 \%), \mathrm{C}_{17: 0} \quad(2 \cdot 9 \%)$, $\mathrm{C}_{18: 1} \omega 7 c(24 \cdot 1 \%), \mathrm{C}_{18: 0}(2 \cdot 9 \%), 11$-methyl $\mathrm{C}_{18: 0} \omega 7 c$ $(1 \cdot 2 \%), \mathrm{C}_{19: 0}$ cyclo $\omega 8 c(51 \cdot 2 \%), \mathrm{C}_{18: 1} 2-\mathrm{OH}(1 \cdot 0 \%)$ and $\mathrm{C}_{20: 2} \omega 6,9 c(0 \cdot 8 \%)$. Aesculin is not hydrolysed. Flexirubinlike pigments and fluorescence are absent. Acid production 
Table 1. Differential characteristics of strain CC-BB $4^{\top}$ and related taxa

Taxa: 1, strain CC-BB4 ${ }^{\mathrm{T}}$; 2, Angulomicrobium (data from Fritz et al., 2004); 3, L. monachus (data from Miller et al., 2005 unless indicated); 4, L. methylaminiphilus (data from Miller et al., 2005); 5, Methylorhabdus (Doronina et al., 1995); 6, Methylarcula (Doronina et al., 2000); 7, Aminobacter (Kämpfer et al., 2002); 8, Methylopila (Doronina et al., 1998); 9, 'Methylosulfonomonas' (Holmes et al., 1997). Symbols: +, positive; -, negative/not detectable; W, weak; NR, not reported.

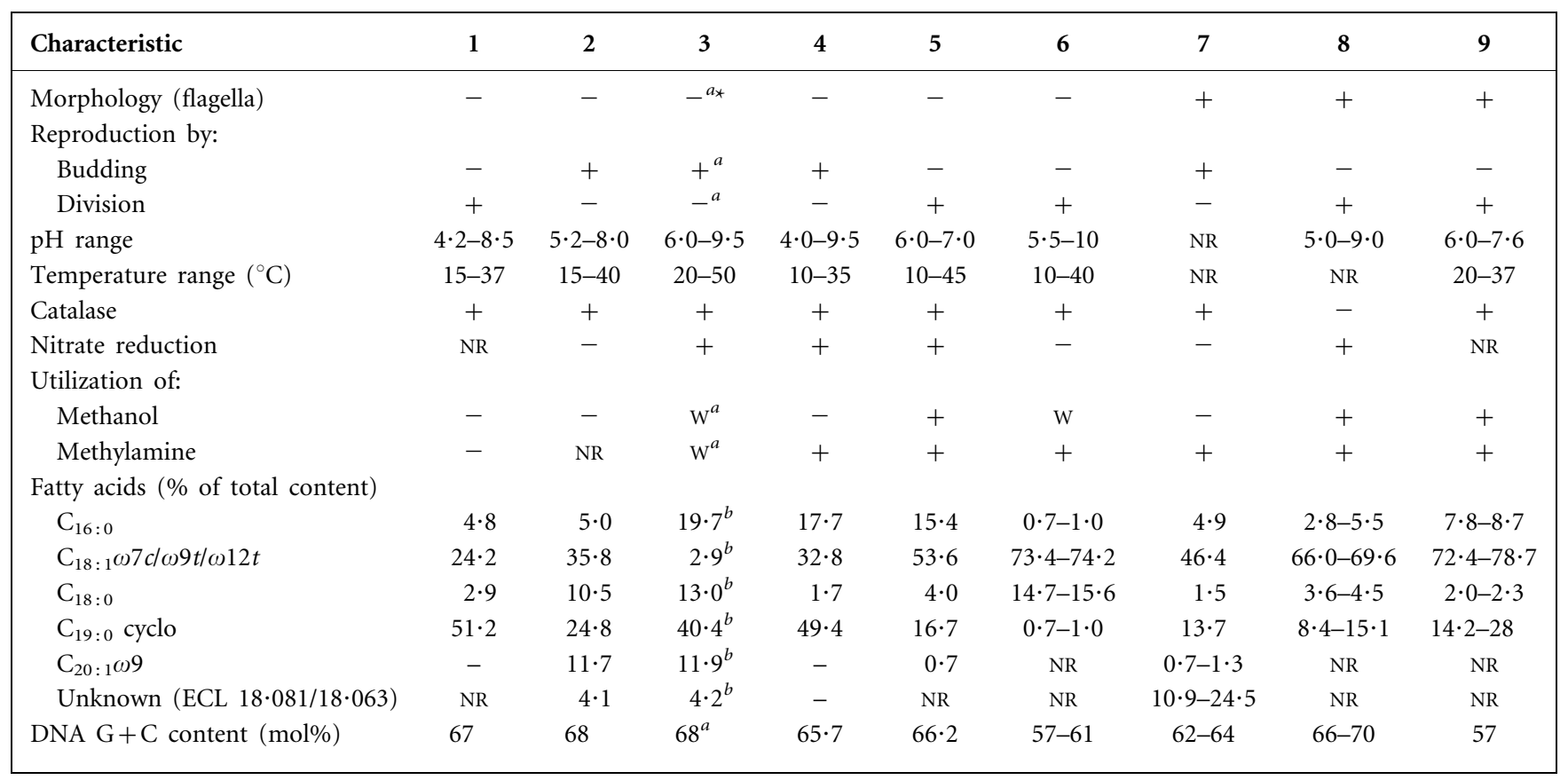

${ }^{\star}$ Data from other studies as follows: $a$, Vasil'eva \& Semenov (1984); b, Fritz et al. (2004).

is negative from glucose, lactose, sucrose, D-mannitol, dulcitol, salicin, adonitol, inositol, rhamnose, maltose, trehalose, cellobiose, D-arabitol, D-mannose, sorbitol, Larabinose, raffinose, D-xylose, methyl D-glucoside, erythritol and melibiose. The following carbon sources are utilized (method according to Kämpfer et al., 1991 and Biolog GN2): acetate, cis- and trans-aconitate, fumarate, DL-3-hydroxybutyrate, DL-lactate, L-malate (weakly), mesaconate (weakly), 3-hydroxybenzoate, succinic acid, bromosuccinic acid, succinamic acid, formic acid, $\alpha$-ketoglutaric acid, pyruvic acid methyl ester and succinic acid monomethyl ester. The following tests are negative (Biolog GN2): $\alpha$-cyclodextrin, dextrin, glycogen, Tweens 40 and $80, \mathrm{~N}$ acetyl-D-galactosamine, $N$-acetyl-D-glucosamine, adonitol, L-arabinose, D-arabitol, D-cellobiose, i-erythritol, Dfructose, L-fucose, D-galactose, gentiobiose, $\alpha$-D-glucose, myo-inositol, $\alpha$-D-lactose, lactulose, maltose, D-mannitol, $\mathrm{D}$-mannose, D-melibiose, methyl $\beta$-D-glucoside, D-psicose, D-raffinose, L-rhamnose, D-sorbitol, sucrose, D-trehalose, turanose, xylitol, citric acid, D-galactonic acid lactone, Dgalacturonic acid, D-gluconic acid, D-glucosaminic acid, D-glucuronic acid, $\alpha$ - and $\gamma$-hydroxybutyric acids, $p$ hydroxyphenylacetic acid, itaconate, $\alpha$-ketobutyric acid, $\alpha$ ketovaleric acid, quinic acid, D-saccharic acid, sebacic acid, glucuronamide, L-alaninamide, D- and L-alanine, L-alanyl glycine, L-asparagine, L-aspartic acid, L-glutamic acid, glycyl
L-aspartic acid, glycyl L-glutamic acid, L-histidine, hydroxyL-proline, L-leucine, L-ornithine, L-phenylalanine, L-proline, L-pyroglutamic acid, D- and L-serine, L-threonine, DL-carnitine, $\gamma$-aminobutyric acid, urocanic acid, inosine, uridine, thymidine, phenylethylamine, putrescine, 2aminoethanol, 2,3-butanediol, glycerol, DL- $\alpha$-glycerol phosphate, $\alpha$-D-glucose 1-phosphate, D-glucose 6-phosphate, salicin, $p$-arbutin, D-xylose, maltitol, adipate, pyruvate, azelate, suberate, L-tryptophan, 4-hydroxybenzoate and phenylacetate. Positive for hydrolysis of L-alanine $p$ nitroanilide ( $\mathrm{pNA}$ ). Negative for hydrolysis of $p$-nitrophenyl (pNP) $\beta$-D-glucopyranoside, $o$-nitrophenyl D-galactopyranoside (ONPG), pNP $\beta$-D-glucuronide, $\mathrm{pNP} \alpha$-D-glucopyranoside, $\mathrm{pNP} \beta$-D-xylopyranoside, bis-pNP phosphate, $\mathrm{pNP}$ phenylphosphonate, pNP phosphorylcholine, 2-deoxythymidine-5'-pNP phosphate, L-glutamate- $\gamma$-3-carboxy pNA and L-proline pNA (method according to Kämpfer et al., 1991). Positive results (API ZYM) are seen for activities of esterase, esterase lipase, lipase (weak), leucine arylamidase and naphthol-AS-BI-phosphohydrolase, while results are negative for alkaline phosphatase, valine arylamidase, cystine arylamidase, trypsin, $\alpha$-chymotrypsin, acid phosphatase, $\alpha$-galactosidase, $\beta$-galactosidase, $\beta$-glucuronidase, $\alpha$-glucosidase, $\beta$-glucosidase, $N$-acetyl- $\beta$-glucosaminidase, $\alpha$-mannosidase and $\alpha$-fucosidase. Additional physiological features are given in Table 1. 
The type strain, $\quad$ CC-BB4 ${ }^{\mathrm{T}} \quad\left(=\mathrm{CCUG} \quad 51779^{\mathrm{T}}=\mathrm{CIP}\right.$ $108932^{\mathrm{T}}$ ), was isolated from soil from Sinshe in Taichung County, Taiwan.

\section{Acknowledgements}

This research work was kindly supported by a grant from the National Science Council and the Council of Agriculture, Executive Yuan, Taiwan, ROC. We thank W. S. Huang for technical assistance. We also thank M. Valens for DNA G $+\mathrm{C}$ content determination and Jean Euzéby for his advice regarding the nomenclature.

\section{References}

Doronina, N. V., Braus-Strohmeyer, S. A., Leisinger, T. \& Trotsenko, Y. A. (1995). Isolation and characterization of a new facultatively methylotrophic bacterium: description of Methylorhabdus multivorans gen. nov., sp. nov. Syst Appl Microbiol 18, 92-98.

Doronina, N. V., Trotsenko, Y. A., Krausova, V. I., Boulygina, E. S. \& Tourova, T. P. (1998). Methylopila capsulata gen. nov., sp. nov., a novel non-pigmented aerobic facultatively methylotrophic bacterium. Int J Syst Bacteriol 48, 1313-1321.

Doronina, N. V., Trotsenko, Y. A. \& Tourova, T. P. (2000). Methylarcula marina gen. nov., sp. nov. and Methylarcula terricola sp. nov.: novel aerobic, moderately halophilic, facultatively methylotrophic bacteria from coastal saline environments. Int J Syst Evol Microbiol 50, 1849-1859.

Fautz, E. \& Reichenbach, H. (1980). A simple test for flexirubin-type pigments. FEMS Microbiol Lett 8, 87-91.

Fritz, I., Strömpl, C. \& Abraham, W. R. (2004). Phylogenetic relationships of the genera Stella, Labrys and Angulomicrobium within the 'Alphaproteobacteria' and description of Angulomicrobium amanitiforme sp. nov. Int J Syst Evol Microbiol 54, 651-657.

Gerhardt, P., Murray, R. G. E., Wood, W. A. \& Krieg, N. R. (editors) (1994). Methods for General and Molecular Bacteriology. Washington, DC: American Society for Microbiology.

Hanson, R. S. \& Hanson, T. E. (1996). Methanotrophic bacteria. Microbiol Rev 60, 439-471.

Holmes, A. J., Kelly, D. P., Baker, S. C., Thompson, A. S., De Marco, P., Kenna, E. M. \& Murrell, J. C. (1997). Methylosulfonomonas methylovora gen. nov., sp. nov., and Marinosulfonomonas methylotropha gen. nov., sp. nov.: novel methylotrophs able to grow on methanesulfonic acid. Arch Microbiol 167, 46-53.

Kämpfer, P. (1990). Evaluation of the Titertek-Enterobac-Automated System (TTE-AS) for identification of members of the family Enterobacteriaceae. Zentralbl Bakteriol 273, 164-172.
Kämpfer, P. \& Kroppenstedt, R. M. (1996). Numerical analysis of fatty acid patterns of coryneform bacteria and related taxa. Can J Microbiol 42, 989-1005.

Kämpfer, P., Steiof, M. \& Dott, W. (1991). Microbiological characterisation of a fuel-oil contaminated site including numerical identification of heterotrophic water and soil bacteria. Microb Ecol 21, 227-251.

Kämpfer, P., Neef, A., Salkinoja-Salonen, M. S. \& Busse, H.-J. (2002). Chelatobacter heintzii (Auling et al. 1993) is a later subjective synonym of Aminobacter aminovorans (Urakami et al. 1992). Int J Syst Evol Microbiol 52, 835-839.

Kämpfer, P., Dreyer, U., Neef, A., Dott, W. \& Busse, H.-J. (2003). Chryseobacterium defluvii sp. nov., isolated from wastewater. Int J Syst Evol Microbiol 53, 93-97.

Kumar, S., Tamura, K., Jakobsen, I.-B. \& Nei, M. (2001). MEGA2: molecular evolutionary genetics analysis software. Bioinformatics 17, 1244-1245.

McDonald, I. R. \& Murrell, J. C. (1997). The methanol dehydrogenase structural gene $m x a F$ and its use as a functional gene probe for methanotrophs and methylotrophs. Appl Environ Microbiol 63, 3218-3224.

McDonald, I. R., Kenna, E. M. \& Murrell, J. C. (1995). Detection of methanotrophic bacteria in environmental samples with the PCR. Appl Environ Microbiol 61, 116-121.

Miller, J. A., Kalyuzhnaya, M. G., Noyes, E., Lara, J. C., Lidstrom, M. E. \& Chistoserdova, L. (2005). Labrys methylaminiphilus sp. nov., a novel facultatively methylotrophic bacterium from a freshwater lake sediment. Int J Syst Evol Microbiol 55, 1247-1253.

Peña, A., Valens, M., Santos, F., Buczolits, S., Antón, J., Kämpfer, P., Busse, H.-J., Amann, R. \& Rosselló-Mora, R. (2005). Intraspecific comparative analysis of the species Salinibacter ruber. Extremophiles 9, 151-161.

Thompson, J. D., Gibson, T. J., Plewniak, F., Jeanmougin, F. \& Higgins, D. G. (1997). The CLUSTAL_X windows interface: flexible strategies for multiple sequence alignment aided by quality analysis tools. Nucleic Acids Res 25, 4876-4882.

Vasil'eva, L. V. \& Semenov, A. M. (1984). New budding prosthecate bacterium Labrys monahos with radial cell symmetry. Microbiology (English translation of Mikrobiologiia) 53, 68-75.

Widdel, F. \& Bak, F. (1992). Gram-negative mesophilic sulfatereducing bacteria. In The Prokaryotes, pp. 3352-3378. Edited by A. Balows, H. G. Trüper, M. Dworkin, W. Harder \& K. H. Schleifer. New York: Springer.

Young, C.-C., Kämpfer, P., Shen, F.-T., Lai, W.-A. \& Arun, A. B. (2005). Chryseobacterium formosense sp. nov., isolated from the rhizosphere of Lactuca sativa L. (garden lettuce). Int J Syst Evol Microbiol 55, 423-426. 